\title{
Sustainability indicators in the context of family farming: A systematic and bibliometric approach
}

\author{
Janaína Wohlenberg ${ }^{1,2}$, Rosana C. S. Schneider ${ }^{1 \dagger}$, Michele Hoeltz ${ }^{3}$ \\ ${ }^{1}$ School Environmental Technology Postgraduate Program, University of Santa Cruz do Sul (UNISC), Santa Cruz do Sul, RS, Brazil \\ ${ }^{2}$ Federal University of the Pampa (UNIPAMPA), Dom Pedrito, RS, Brazil \\ ${ }^{3}$ InocullaTech - Research and Development in Natural Science, Santa Cruz do Sul, RS, Brazil
}

\begin{abstract}
Actions that promote the sustainability of small-scale agricultural activities are fundamental to maintaining the supply and diversification of products, generating income, and minimizing their environmental impact. This study aimed to identify the main economic, environmental, and social indicators used in studies focused on food production by family farming. A systematic literature review was performed in the Scopus database, where 22 original articles were identified. The largest number of publications was observed in Italy and the United States of America, followed by Brazil, India, Poland, and the United Kingdom. The main aspect observed in the publications was the interrelationship of the three spheres of sustainability, highlighting the importance of integrated monitoring. Some indicators identified were: in the economic sphere, financial planning, productivity, and profitability; in the environmental sphere, soil use and quality, water, erosion, temperature, and energy; and in the social sphere, food security, job and income generation, and government subsidies. A holistic approach to the use of monitoring indicators as a tool for sustainability is fundamental, but there are few studies that evaluate these three spheres; mainly in the field of agribusiness, due to its greater diversity of activities and aspects to be monitored.
\end{abstract}

Keywords: Family farm, Food production, Indicators, Sustainability, Triple bottom line

\section{Introduction}

The main global challenges of today are related to poverty eradication, food security and environmental pressures [1]. In 2015, the 17 Sustainable Development Goals (SDGs) were established so that each Member State of the United Nations (UN) would commit to actions to be followed by the 2030 Agenda for Sustainable Development [2]. This meeting marked the representativeness of family farming relating to the reach of the established SDGs. According to the study presented by Graeub et al. [3], family labor is responsible for at least $53 \%$ (fifty-three percent) of the world's food supply and, it is estimated that there are more than 500 million small family farms in the world.

Given the exponential population growth and the growing demand for food, family farming is one of the main suppliers to meet this current need $[4,5]$; besides being directly linked to diversification in product supply [5-7]; food and nutrition security [1]; and poverty reduction [8]. This reality points to the need for the development of more productive, profitable and efficient rural prop- erties in the use and allocation of resources, as well as public policies to assist this activity; and, in parallel with these issues, environmentally conscious with the reflexes of its activities towards the environment [8-11].

Quintero-Angel et al. [12] emphasize that activities carried out in rural areas involve higher anthropogenic intervention in ecosystems, highlighting the importance of developing assessment methodologies appropriate to the particularities of each productive system, making them more efficient while reducing their environmental impact; as well as guiding the decision-making processes of managers to a more sustainable holistic vision.

According to Galdeano-Gómez et al. [10], this field of research aimed at measuring sustainability in agriculture has been growing as a result of the need for balanced actions to face the challenges imposed by modern society and the growing demand for food. To this end, different practices have been developed seeking to preserve ecosystems through measures to restructure agricultural production, with production processes of lower impact, efficient
This is an Open Access article distributed under the terms of the Creative Commons Attribution Non-Commercial License (http://creativecommons.org/licenses/by-nc/3.0/) which permits unrestricted non-commercial use, distribution, and reproduction in any medium, provided the original work is properly cited.

Copyright (C) 2022 Korean Society of Environmental Engineers
Received September 27, 2020 Accepted December 21, 2020

${ }^{\dagger}$ Corresponding author

E-mail: rosana@unisc.br

Tel: +55 51 3717-7545 Fax: +55 51 3717-7545

ORCID: 0000-0003-1400-8401 
use of resources, minimizing the generation of waste, and adequate alternatives for waste disposal and/or valuation [1, 11-14]. Other practices used to boost activities in agribusiness, which respect environmental aspects, are crop-livestock integration [15] and impact monitoring with the use of indicators [16], making farms more competitive and sustainable. In the family farm, there is a need for maximum efficiency in the use of natural resources since it integrates the process of crop rotation and the use of the same land space for livestock, promoting the control of the degradation process through conservationist practices.

In this context, indicators are presented as tools used to monitor certain factors, transmitting information about the achievement or not of an established goal or minimum standard, identifying non-conformities in a system, and contributing a range of information about the organizational picture, supporting the decision-making process [17]. Banu [18] corroborates the importance of identifying and defining key indicators appropriate to the structure to be measured and the intended results, calling them KPIs - Key Performance Indicators.

The objective of the indicators is to make the significance of a phenomenon more apparent and easy to understand, since they unify and quantify information, simplifying it, and enabling it to be easily understood [19]. Therefore, they are important tools for describing the sustainability of systems, providing data capable of assisting in the formulation of public policies, and strategic and business decision-making [20].

The sustainability indicators are composed of different indicators, such as: environmental (air quality, water quality, energy consumption), social (quality of life, well-being, income distribution), and economic (consumption and production pattern, liquidity), and can act jointly, forming indexes, or separately, in the three spheres that comprise sustainability [21-23]. The combination of these three spheres is also known as the "three pillars" of sustainability or the triple bottom line - TBL. The implementation of TBL indicators includes measuring sustainability in its three spheres of scope and is gaining importance for the provision of information by public and private companies to stakeholders [24, 25].

The main difficulty in developing indicators based on the three pillars of sustainability is due to the fact that there is neither a universally accepted system or package, nor a universally established unit of measurement that can be used to measure the performance of organizations [17, 23, 26]; this fact, according to Sulewski et al. [27], corroborates the scarcity of published works covering the three spheres concomitantly.

This study aimed to identify, through a systematic and bibliometric analysis, the main scientific and original publications that address the use of indicators involving the three spheres of TBL. Thus, it is expected to contribute to the discussion on the importance of working on a holistic vision, considering the social, economic, and environmental spheres, through monitoring indicators as a tool for sustainable development objectives in the context of food production by family farming.

\section{Methodology}

To identify the sustainability indicators focused on the food pro- duction scenario by family farming, a systematic and bibliometric survey of original publications from the last 5 years (2015 to May 2020) was conducted following a pre-established research protocol described in the PRISMA protocol (Preferred Reporting Items for Systematic Reviews and Meta-Analyses) (Fig. 1), and considering the clear and current definition of sustainability indicators as a premise. The results were extracted from the Scopus platform, as it is the database with the greatest diversity of scientific and technical journals of global reach.

As a search index, words contained in the title, abstract, and keywords were used. The search words were used together with the Boolean marker "AND" to restrict the results based on the search focus. The search process was initiated by the "Sustainability" AND "Indicator" terminologies, where 6,858 publications were found, and it was observed that about 99\% were not related to the focus of this search, requiring a refinement process. Additional "Small Farm" AND "Food" terminologies were used in the refinement, resulting in a sample of 52 publications. Initially, the abstract of these articles was read to verify if they met the eligibility criteria - with reference to indicators, with reference to food production, and with reference to family farming. It was observed that 19 of the 52 articles did not meet all the established criteria. The 33 remaining papers were fully read to verify if they met the last selection criterion, that of contemplating the application of indicators in the three spheres of sustainability concomitantly. In this process, 11 more papers were excluded; leaving 22 original papers that composed the analysis data of this research.

The bibliometric analysis was carried out contemplating the metric systems available in the Scopus database, which provided the quantity of publications per year, country of origin, journal, and main areas of study. After an analysis and discussion of the results, it was possible to identify the main monitoring indicators in the economic, environmental, and social spheres. The bibliographic

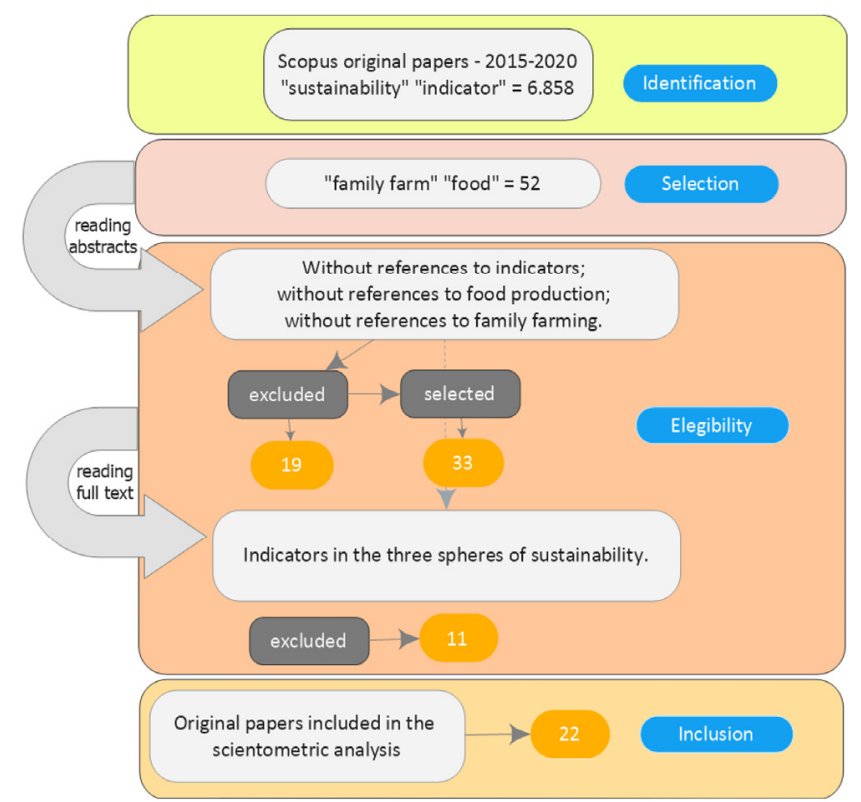

Fig. 1. PRISMA protocol used to select the articles to be analyzed, based on pre-established criteria. 
data analysis was conducted using the software VosViewer 1.6.15 from Leiden University. The software identified clusters among the documents collected by the database and selected by the PRISMA protocol.

Since it is not possible to integrate the information from case studies with Vosviewer, which are published in national journals, the documents were searched through Scielo and Google Scholar, with the same time filters and keywords in Portuguese and Spanish. From 1,306 documents found, 32 original articles were selected to read. Further, it was selected the documents related with TBL concept in the family farm and indicators sustainable context.

\section{Bibliometric Approach}

The field of research aimed at measuring sustainability, once the agroindustrial activities has been growing as a result of the need for balanced actions to face the challenges of modern society and the potential impacts it represents [28]. The 22 articles selected are presented in Table 1 [29-43].

The number of publications related to the use of indicators in the three spheres of TBL in the context of food production by family labor, increased from 9.1\% in 2015 and 2016, 22.7\% in $2017,27.3 \%$ in 2018 , to $31.8 \%$ in 2019 , demonstrating the trend and commitment of academia to develop studies to measure sustainability in rural areas and ensure the goal of food security.

This growing trend in publications on monitoring indicators is perceived by Scherer et al. [7] as the result of increased global demand for food, and due to family labor being the main factor in product supply and diversification. This aspect was highlighted in two selected publications of 2015, which analyze the sustainability of family agriculture based on TBL monitoring indicators; the first aimed to present indicators to provide small rural producers with an immediate assessment of the performance level of their activity [43]; and the second carried out an assessment of different scenarios, considering environmental, economic, and social aspects in agricultural and rural development [42].

In related publications in 2016, the importance of family farming for sustainability is emphasized, highlighting contributions related to the use of short supply chains [41] and the need to maintain family farming activity in the long term [40].

In 2017, the indicator approaches focused on food security as- pects [39], family succession [28], new technologies [38], agroecological practices [21], and the impact of economic and social pressures on environmental aspects [10].

The year 2018 is also marked by the use of agroecological practices such as sustainable development alternatives [37], organic production [36], efficiency in the use of economic and environmental resources [35], collaboration among members of the same chain [34], and the relationship between the dimensions of TBL [27].

The implementation of TBL indicators has gained importance in organizations and can be a powerful tool for evaluation in family farming units, reflecting the quality of the environment in which it is inserted, in terms of profitability, social, human, and environmental capital [44]. Dočekalová et al. [17], Hák et al. [45] and Huguet Ferran et al. [26] emphasize that the assessment of sustainability and the aggregation of a set of individual indicators depends on how researchers will make use of the measurement tools, in order to arrive at the final result, which can be applied to different organizational conditions and with a holistic approach. In view of this, there is no impediment or limitation to the valorization of family farming with a sustainable organizational approach, both regarding the indicators and the ways in which certain aspects will be measured, leaving the task of the researcher to explore the variables based on the literature, examining the successes already achieved with measuring tools previously applied, and looking at the three pillars of the TBL.

Finally, the year 2019 is marked by studies on the impacts of agricultural intensification [32], the relationship between geophysical requirements, ecological practices, economic and welfare aspects [31], certifications [30], agroecological practices [23], the relationship between TBL dimensions and aspects affecting them [5, 29], and short supply chains [22].

In general, the selected publications consider the main themes addressed to promote sustainability in family agricultural production, demonstrating the use of agroecological practices, the use of short chains and cooperation among members of the same chain, and, especially, the feedbacks resulting from interactions between the spheres of TBL, emphasizing the importance of understanding the environment in a systemic way. It also became evident that, in the last 5 years, the search for measures to promote sustainability within the context of food production by family farming has gained representativeness.
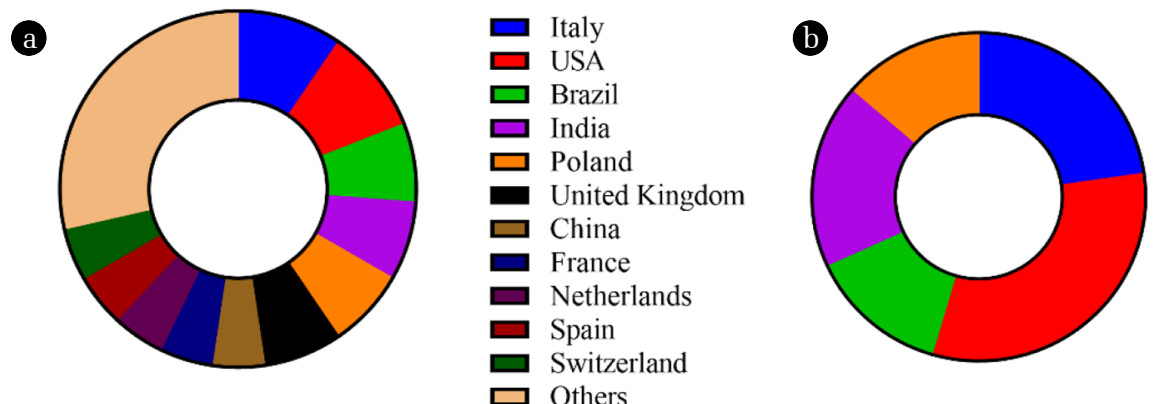

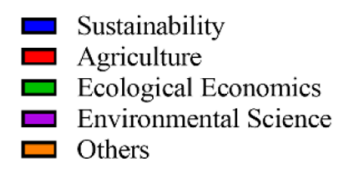

Fig. 2. Number of publications and country of origin with the highest occurrence of original documents (a) and by main themes (b), in the period from 2015 to 2020, related to sustainability indicators for the food sector of family farming. 


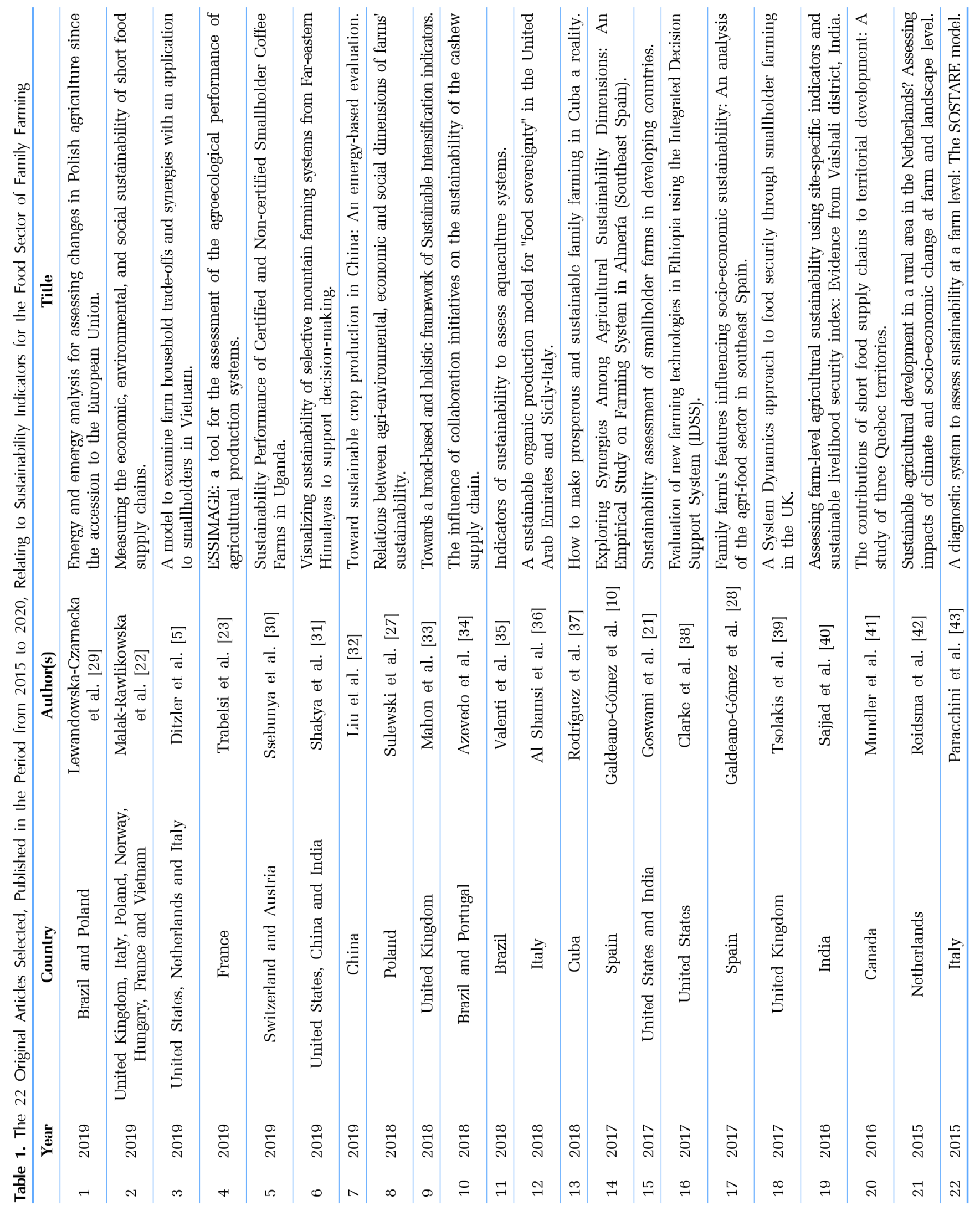




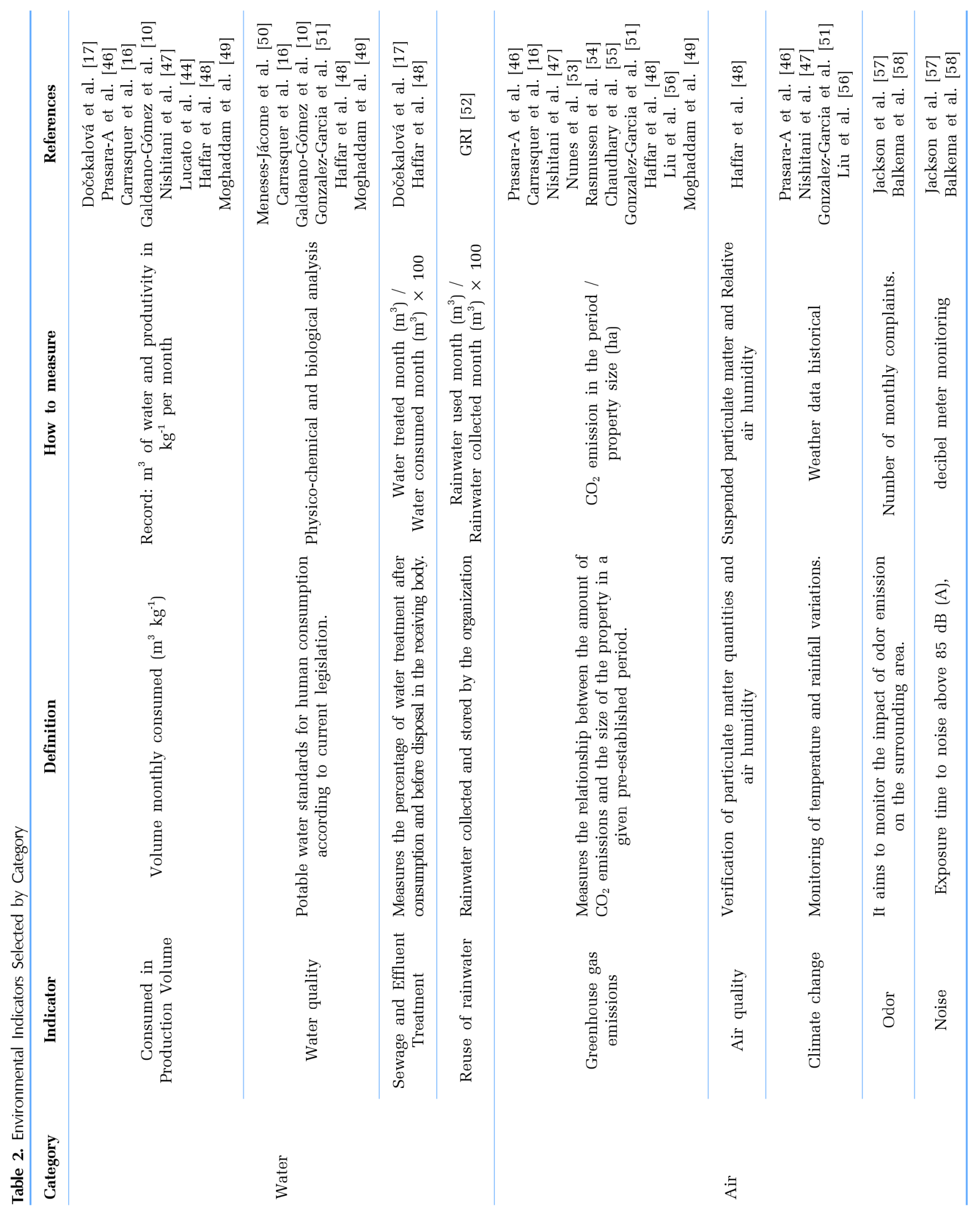




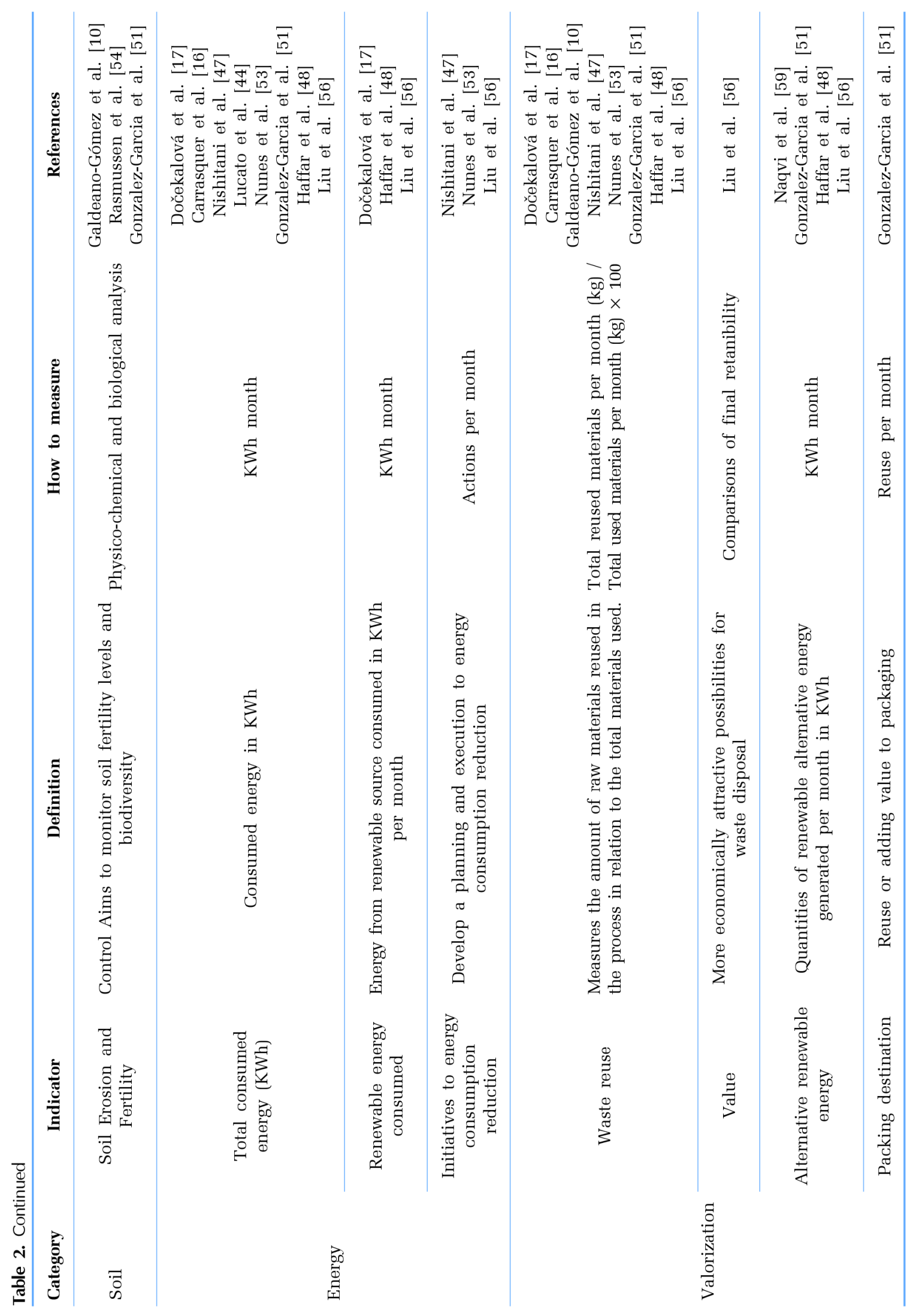




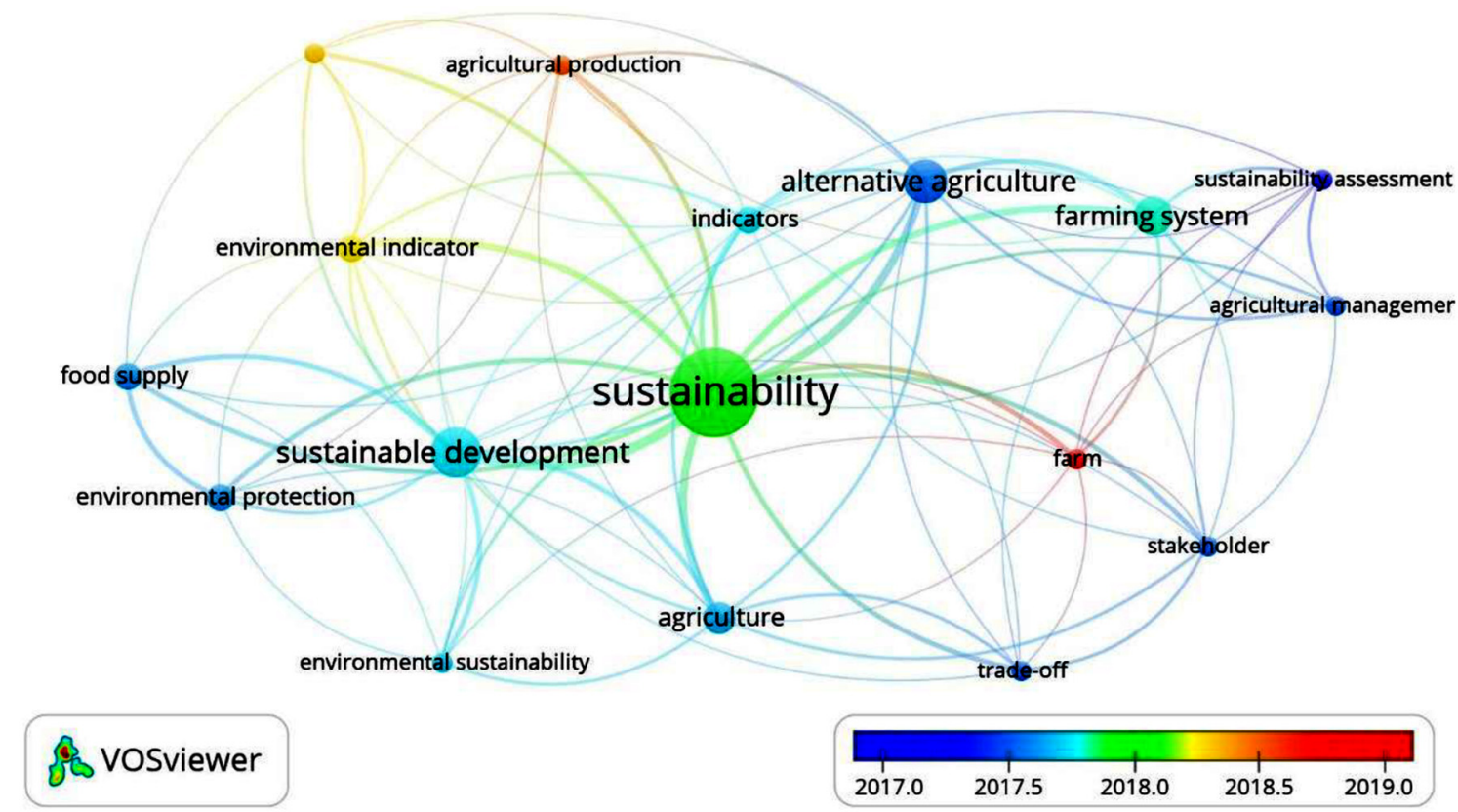

Fig. 3. Developed themes associated to sustainability indicators for the food sector of family farming from 2015-2020.

Taking into consideration the country of origin, it was possible to observe that Italy and the United States lead the ranking with 4 publications each; followed by Brazil, India, Poland, and the United Kingdom with 3 publications; China, France, the Netherlands, Spain, and Switzerland with 2; and the other countries with only one publication, as can be seen in Fig. 2. Cooperation among countries with more publications is also a positive trend that can be verified in the works developed, mainly by India and the USA. These countries have developed research in a cooperative way, sharing experiences, and enabling knowledge enrichment.

Brazil presented 3 publications, the most recent published in 2019 in cooperation with Poland, in which aspects related to energy efficiency and environmental sustainability are discussed after Poland's accession to the European Union (EU). The other two publications date from 2018; one, in partnership with Portugal, highlighting the environmental, economic, and social aspects of cooperation in the cashew supply chain; and, published singularly, a work describing sustainability indicators in aquaculture practice.

The main themes addressed by the highlighted countries, Italy and the United States are focused on the maintenance of agricultural activity in a sustainable way, seeking to guarantee income and subsistence for families, production and diversification of food, social welfare, and zeal for environmental aspects, especially soil fertility. Regarding the main study areas, it was observed that Environmental (29.2\%), Social (20.8\%), Agricultural (16.7\%), and Energy (14.6\%) aspects are the most relevant in the selected studies, as can be seen in Fig. 3 based on the key word citations and Table 2 [46-59] shows the main environmental indicators for measuring sustainability found in documents of the last 5 years and some indicators found only before 2015 (odors, reuse of rainwater, and noise).

\section{Indicators of Sustainability and Family Farming}

Thus, indicators can reflect complexity presenting results that are easy to understand, guiding decision-making regarding the environmental policy to be adopted by managers [60]. When grouped into categories, indicators can improve aspects related to air, soil, water, biodiversity, energy, and others [48]. The grouping of environmental indicators is proposed for the preparation of Global Reporting Initiative (GRI) reports considering materials, energy, water, biodiversity, emissions, effluent, and conformity. Also, according to Haffar et al. [48], to obtain eco-efficiency, indicators can be established based on an analysis of the performance areas of organizational activities.

Monitoring indicators are versatile tools and should be selected and adjusted according to the proposed objectives and the organization's internal capacity to obtain the necessary data for the total analysis. In this way, there is no universal standard for indicators, they are designed for each reality to be analyzed [18]. After reading the selected articles, it was possible to observe that each study considers a particular feature in the use of indicators, based on the needs of the objectives of each research. Therefore, with respect to measurement by indicators, different goals and environmental scenarios require different indicators [61] and, when defining a group of personalized indicators, new monitoring standards can be established, with predicted indices or trends to be observed, establishing a standard to be adopted by the organization [17].

In the current context, consideration should be given to the choice of indicators, striving for a simplified selection, so that the results can be useful to the management process. These tools can be used to demonstrate the results to stakeholders as well as being an excellent internal monitoring tool, for example, to control the amount of raw material used in the production process and the amount of waste generated from each activity. 
Table 3. Sustainability Indicators for the Food Sector of Family Farming Used in the Analyzed Articles

\begin{tabular}{|c|c|c|}
\hline Economic Indicators & Environmental Indicators & Social Indicators \\
\hline Financial planning & Renewable energy & Age \\
\hline Third party equity participation & Non-renewable energy & Gender \\
\hline Productivity & Non-renewable resources & Race \\
\hline Hours worked & Soil fertility & Schooling \\
\hline Control of materials used & Erosion & Employment \\
\hline Sales & Siltation & Labor rights \\
\hline Profitability & Water quality & Company image \\
\hline Profit on sales & Water use & Social responsibility in the acquisition of supplies \\
\hline Net profit & Land use & Negotiating power \\
\hline Internal rate of return & Re-use of water & Quality of life \\
\hline Payback & Use of rainwater & Nutrition \\
\hline Net present value & Waste water treatment & Food safety \\
\hline Added value & Air quality & Animal welfare \\
\hline Product diversification & Biodiversity & Social involvement \\
\hline Quality of the final product & Environmental load & Intensity (working hours) and manual work \\
\hline Packaging & Greenhouse Gases - GHGs & Government subsidies \\
\hline Investments & Nitrogen (N) & Community initiatives \\
\hline Arable area & Temperature & Local governance \\
\hline Machinery used & Eutrophication & Rural exodus \\
\hline Marketing channels and cooperation networks & Solar lighting & Family succession \\
\hline Price oscillation in the market & Food miles & Gross Domestic Product - GDP \\
\hline Channels of purchase & Agro-ecological practices & Income distribution \\
\hline \multirow[t]{8}{*}{ Relationship with suppliers } & Fertilizers & Basic sanitation \\
\hline & Natural area & Farm size \\
\hline & & Inclusive growth \\
\hline & & Participation in cooperatives \\
\hline & & Income dependent on agriculture \\
\hline & & Training courses \\
\hline & & Local tourist exploitation \\
\hline & & Odor (surrounding) \\
\hline
\end{tabular}

The monitoring indicators identified were compiled in order to highlight the current overview of the use of indicators in the context of food production by family farming, in the three spheres that make up sustainability, concomitantly. These results are presented in Table 3. According to Simas et al. [62], a good indicator warns of a potential problem, before it becomes established, favoring early decision-making. In communities in crisis (whether social, economic, or environmental), indicators help to point out factors that deserve more attention and identify alternative solutions to these problems, in order to contribute to proactive decision making, minimizing the possibility of future negative impacts.

It was possible to identify greater uniformity in the use of indicators from the economic and environmental spheres, the same sequence of indicators being chosen when the research objectives were similar. However, when observed from the perspective of the social sphere, it was identified that there is still no consensus among the authors, a fact demonstrated by the wide variety of social indicators used. This fact can be observed in the works of Paracchini et al. [43], Clarke et al. [38], Galdeano-Gómez et al. [10], Mahon et al. [33], Sulewski et al. [27], Valenti et al. [35], Shakya et al. [31], Ssebunya et al. [30] and Trabelsi et al. [23], in which the authors used similar indicators in the economic and environmental spheres to achieve their final objectives, with the measurement of financial planning, productivity, water quality, and soil fertility being present. This similarity of indicators was not observed in the social sphere.

With regard to economic indicators, it was possible to identify the importance of their use for farmers' long-term economic stability. 
According to Lewandowska-Czarnecka et al. [29], these indicators are extremely relevant for the agricultural sector, since the production costs and returns obtained directly reflect the economic capacity of farms; however, sustainability indicators monitored should be adapted to the local reality, adopting a holistic view of the system, in order to understand the process as a whole, and the main aspects that may compromise organizational economic stability. Bui et al. [63] corroborate the need for financial management and agricultural practices as factors that impact the increase in productivity and development in rural areas.

This view on the importance of the economic system in relation to the stability of activities in the rural area is due to the capitalist system, where profit is the main aspect. However, more than 20 years ago Tisdell [64], described that agricultural systems have some particularities in the process of monitoring and forecasting financial demand, since some factors are involved that are independent of control, such as the seasonality of production and bad weather, which compromises the predictability of production yields and, consequently, the generation of financial results related to liquidity, requiring greater attention from managers. Considering the documents from 2019/2 (August to December) and 2020/1 (January to August) relating to family farms and sustainability, we found clusters of research as presented in Fig. 4. This figure represents evidence of the current importance of indicators associated to spatial analysis, ecosystems, risks, adaptation, and trade-off, as well as the relevance to food production for the family farm. It is observed that innovation is a way for small farms to survive and, in this last year, using the key words "family farm" and "sustainability", environmental, social, and economic issues appeared to be associated with land use, rural exodus, and food production.

In general, with regard to environmental aspects, studies have shown a concern for soil fertility, water quality, erosion, climate change, and the use of energy from renewable sources. According to Cox et al. [65], soil and water quality are determining factors for agricultural productivity. The study demonstrated that sustainability in agriculture depended on adequate water, soil, and crop management practices and that monitoring by indicators was indispensable for managing the farm and for obtaining a history of its evolution based on the decisions made.

In the social sphere, as described, the lack of a pattern in the use of indicators was observed, but some aspects were highlighted such as the importance of minimizing the rural exodus, government subsidies, quality of life and nutrition, and the role of local governance as factors directly related to the permanence of the workforce in rural areas. One factor that contributes to the permanence of small rural farms is related to the well-being of the family workforce in carrying out its activity in rural areas [66].

A survey of social indicators, at the government management level, is also essential to identify the present needs and trends, including for the permanence of families in rural areas, since many of them depend on government subsidies as a form of income supplementation [67].

Another social aspect is highlighted by Sjauw-Koen-Fa et al. [68], who address the need for farmers to group into cooperatives, facilitating the implementation of management processes, such as monitoring by indicators, in addition to enabling participation in certification programs facilitating access to new markets and

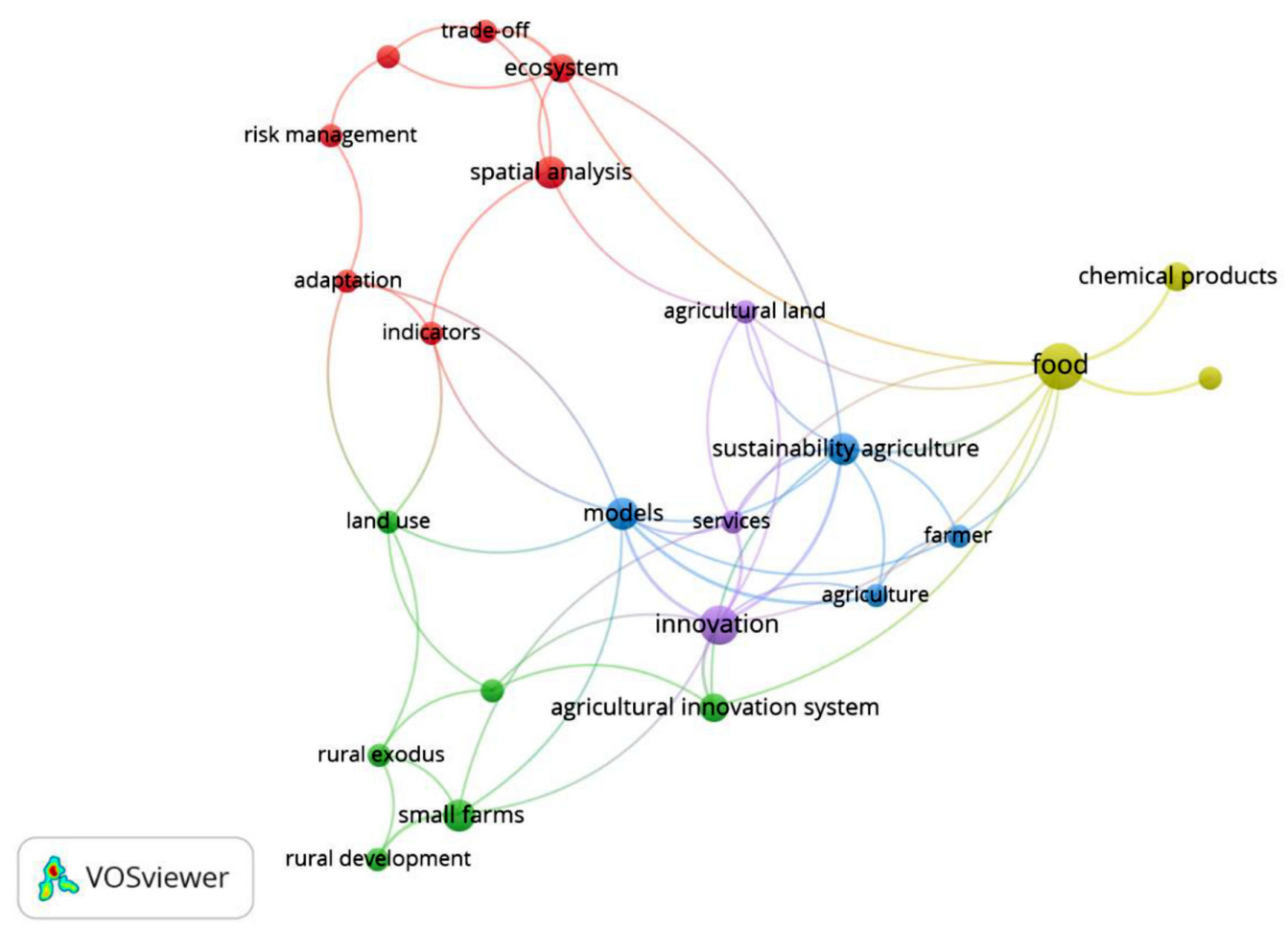

Fig. 4. Clusters obtained from research documents in the year(2019/2 to 2020/1). 
to socioeconomic benefit programs, since most producers directly market their products to final consumers. Organizing producers into cooperatives is also seen as a strategic alternative with the purpose of strengthening the capacity to supply products, management practices, and price negotiation, ensuring the means necessary for the subsistence and permanence of farmers in the activity [22, 69]. However, Malak-Rawlikowska et al. [22] believe that short supply chains are more sustainable compared to mass food delivery systems, and are more economically viable for farmers, as they eliminate the capture of a profit margin attributed to the different intermediaries of a long chain.

In the study presented by Galdeano-Gómez et al. [10], a series of environmental, social, and economic indicators is presented based on the Sustainable Agriculture, Food, and Environment (SAFE) Platform, with the purpose of carrying out an analysis of sustainability indicators and their interrelationships in family farming systems in vegetable production. It has been demonstrated that there is an inter-relationship between the spheres due to the increase in economic and social indicators reducing environmental pressures on resource use and, in parallel, social and environmental improvements reveal positive effects on the economic dimension of farmers, these factors being directly linked to the physical structure and activities developed on the farms, such as biological techniques, pest control, and organic production.

The management of productive activities in the different economic sectors has been developed from the need for planning, both of the resources used, as well as the dimensioning of the capacity and of the major productive efficiency, in order to obtain competitive advantage, greater market gain, and greater profit. Economic indicators are the main tool used to monitor the performance of strategic management in order to maintain financial stability, assisting managers in the decision-making process and in the long-term economic viability of the activity [70]; since, maintaining organizational liquidity has become an even greater challenge due to the expansion of global trading boundaries [44].

Agricultural systems have some peculiarities in the process of monitoring and forecasting financial demand, since they involve factors independent of control, such as seasonality of production and inclement weather. These factors may compromise the production forecasting process and the generation of financial results related to liquidity and the availability of resources. Since, in rural areas, economic productivity is affected by non-economic factors, monitoring tools must be adapted to this reality, adopting a holistic view of the system, in order to understand the process as a whole and its inference zones.

In the case studies, it was highlighted the economic and social issues and the environmental concern was less worked. Moreover, family farms had some peculiarities in the selection of indicators such as the seasonality of production and bad weather, which undermines the predictability of production yields and hence the generation of financial resources [71-77].

Indicators obtained according to TBL concept allowed to propose sustainability actions beyond the financial control and new marketing channels of the family farm. Some of the sustainability actions were composting organic waste and adoption of other management techniques and soil conservation; construction of cisterns and protection of sources and other water resources; collection of solid waste; cultivation of seedlings and use of creole seeds [78, 79].

The creation of an environmental policy to guide actions on family farms was also suggested. There is a need to assess organic or not organic agrosystems and to establish critical points in the management system, maintenance of biodiversity, crop diversification, soil conservation, recycling of nutrients, weed control, pest and disease control and increased productivity [80, 81].

\section{Conclusions}

Promoting sustainable agriculture is a global trend, so this objective must be pursued, measured, and accompanied with viable planning and strategies. Bibliometric analysis has shown an increasing number of publications focused on the use of indicators in the three spheres of TBL. It was observed that most of these studies originate in Italy and the USA and that environmental indicators are the aspects most addressed in the publications. Although 6,858 papers related to sustainability and indicators were identified, only 22 are related to the objectives of the research, showing that the use of monitoring indicators, used in the three spheres of sustainability, is still a challenge to be explored in the context of family farming.

It was observed that the economic and environmental spheres present a certain "consensus" among the authors, demonstrating a similarity in the use of indicators from these spheres; however, this is not perceived in the social sphere, which resulted in a greater diversity of indicators. In the economic sphere, the main indicators are related to financial aspects, productivity, quality of the final product, commercialization channels, and possibilities of cooperation. In the environmental aspects, the greatest concern is focused on soil fertility and water quality and availability. The studies also presented a concern about climate change, the use of agricultural fertilizers, and greenhouse gas emissions. Despite the diversity of indicators listed in the social sphere, food security, rural exodus, and government subsidies were the main aspects identified for the viability of farmers' livelihoods in rural areas, aiming to ensure the development of the activity and diversification in the supply of agricultural products.

In these aspects, it is also clear that family agriculture needs to be understood as an important sector of the economy to be analyzed within the context of the SDGs and the 2030 Agenda for Sustainable Development in all countries, in the search for sustainability based on the economic, social, and environmental pillars. The study reached the proposed objective by identifying the relationship of monitoring indicators in the three spheres of sustainability used in original and current studies, in the context of food production by family labor. Effective proof of the efficiency of the monitoring indicators along with the activities developed by family farming is a factor to be explored in future works.

\section{Acknowledgment}

This study was funded in part by the National Research Council (CNPq) process 310228/2019-0. 


\section{Author Contributions}

J.W. (Ph. D. student) wrote the manuscript. M.H. (Professor) wrote and revised the manuscript. R.C.S.S. (Professor) revised the manuscript.

\section{References}

1. Wang X, Li Z, Long P, et al. Sustainability evaluation of recycling in agricultural systems by emergy accounting. Resour. Conserv. Recycl. 2017;117:114-124.

2. de Menezes HZ, Minillo XK. Research and extension as a University contribution in the implementation of objectives of sustainable development goals (SDGs) in Brazil. Meridiano 47-J. Global Stud. 2017;18:1-16.

3. Graeub BE, Chappell MJ, Wittman H, Ledermann S, Kerr RB, Gemmill-Herren B. The State of Family Farms in the World. World Dev. 2016;87:1-15.

4. Toader M, Roman GV. Family Farming - Examples for Rural Communities Development. Agric. Agric. Sci. Procedia 2015;6: 89-94.

5. Ditzler L, Komarek AM, Chiang T-W, et al. A model to examine farm household trade-offs and synergies with an application to smallholders in Vietnam. Agric. Syst. 2019;173:49-63.

6. Nunes B, Bennett D, Marques Júnior S. Sustainable agricultural production: an investigation in Brazilian semi-arid livestock farms. J. Clean. Prod. 2014;64:414-425.

7. Scherer LA, Verburg PH, Schulp CJE. Opportunities for sustainable intensification in European agriculture. Global Environ. Change 2018;48:43-55.

8. Dogliotti S, García MC, Peluffo S, et al. Co-innovation of family farm systems: A systems approach to sustainable agriculture. Agric. Syst. 2014;126:76-86.

9. Arora P, Peterson ND, Bert F, Podesta G. Managing the triple bottom line for sustainability: a case study of Argentine agribusinesses. Sustainability: Sci. Pract. Policy 2017;12:60-75.

10. Galdeano-Gómez E, Aznar-Sánchez JA, Pérez-Mesa JC, Piedra-Muñoz L. Exploring Synergies Among Agricultural Sustainability Dimensions: An Empirical Study on Farming System in Almería (Southeast Spain). Ecol. Econ. 2017;140: 99-109.

11. Taveira LRS, Carvalho TSd, Teixeira AFdS, Curi N. Sustainable productive intensification for family farming in developing tropical countries. Ciênc. Agrotecnol. 2019;43:e012819.

12. Quintero-Angel M, González-Acevedo A. Tendencies and challenges for the assessment of agricultural sustainability. Agric. Ecosyst. Environ. 2018;254:273-281.

13. Giuliano A, Bolzonella D, Pavan P, Cavinato C, Cecchi F. Co-digestion of livestock effluents, energy crops and agro-waste: feeding and process optimization in mesophilic and thermophilic conditions. Bioresour. Technol. 2013;128:612-618..

14. Navarrete M, Dupré L, Lamine C. Crop management, labour organization, and marketing: three key issues for improving sustainability in organic vegetable farming. Int. J. Agric. Sustainability 2014;13:257-274.

15. Gil JDB, Garrett R, Berger T. Determinants of crop-livestock integration in Brazil: Evidence from the household and regional levels. Land Use Policy 2016;59:557-568.

16. Carrasquer B, Uche J, Martínez-Gracia A. A new indicator to estimate the efficiency of water and energy use in agro-industries. J. Clean. Prod. 2017;143:462-473.

17. Dočekalová MP, Kocmanová A. Composite indicator for measuring corporate sustainability. Ecol. Indic. 2016;61:612-623.

18. Banu GS. Measuring innovation using key performance indicators. Procedia Manuf. 2018;22:906-911.

19. Dong Y, Hauschilda MZ. Indicators for environmental sustainability. Procedia CIRP 2017;61:697-702.

20. Pupphachai U, Zuidema C. Sustainability indicators: A tool to generate learning and adaptation in sustainable urban development. Ecol. Indic. 2017;72:784-793.

21. Goswami R, Saha S, Dasgupta P. Sustainability assessment of smallholder farms in developing countries. Agroecol. Sustain. Food Syst. 2017;41:546-569.

22. Malak-Rawlikowska A, Majewski E, Wąs A, et al. Measuring the Economic, Environmental, and Social Sustainability of Short Food Supply Chains. Sustainability 2019;11:1-23.

23. Trabelsi M, Mandart E, Le Grusse P, Bord JP. ESSIMAGE: a tool for the assessment of the agroecological performance of agricultural production systems. Environ. Sci. Pollut. Res. Int. 2019;26:9257-9280.

24. Singh RK, Murty HR, Gupta SK, Dikshit AK. An overview of sustainability assessment methodologies. Ecol. Indic. 2012;15: 281-299.

25. Bautista S, Enjolras M, Narvaez P, Camargo M, Morel L. Biodiesel-triple bottom line (TBL): A new hierarchical sustainability assessment framework of principles criteria \& indicators (PC\&I) for biodiesel production. Part II-validation. Ecol. Indic. 2016;69:803-817.

26. Huguet Ferran P, Heijungs R, Vogtländer JG. Critical Analysis of Methods for Integrating Economic and Environmental Indicators. Ecol. Econ. 2018;146:549-559.

27. Sulewski P, Kłoczko-Gajewska A, Sroka W. Relations between Agri-Environmental, Economic and Social Dimensions of Farms' Sustainability. Sustainability 2018;10:1-23.

28. Galdeano-Gómez E, Zepeda-Zepeda JA, Piedra-Muñoz L, Vega-López LL. Family farm's features influencing socio-economic sustainability: An analysis of the agri-food sector in southeast Spain. New Medit 2017;16:50-61.

29. Lewandowska-Czarnecka A, Buller LS, Nienartowicz A, Piernik A. Energy and emergy analysis for assessing changes in Polish agriculture since the accession to the European Union. Ecol. Modell. 2019;412:108819.

30. Ssebunya BR, Schader C, Baumgart L, et al. Sustainability Performance of Certified and Non-certified Smallholder Coffee Farms in Uganda. Ecol. Econ. 2019;156:35-47.

31. Shakya B, Shrestha A, Sharma G, et al. Visualizing Sustainability of Selective Mountain Farming Systems from Far-eastern Himalayas to Support Decision Making. Sustainability 2019;11:

32. Liu Z, Wang Y, Geng Y, et al. Toward sustainable crop production in China: An emergy-based evaluation. J. Clean. Prod. 2019;206:11-26.

33. Mahon N, Crute I, Di Bonito M, Simmons EA, Islam MM. Towards a broad-based and holistic framework of Sustainable 
Intensification indicators. Land Use Policy 2018;77:576-597. 34. Azevedo S, Silva M, Matias J, Dias G. The Influence of Collaboration Initiatives on the Sustainability of the Cashew Supply Chain. Sustainability 2018;10:2075.

35. Valenti WC, Kimpara JM, Preto BdL, Moraes-Valenti P. Indicators of sustainability to assess aquaculture systems. Ecol. Indic. 2018;88:402-413.

36. Al Shamsi KB, Compagnoni A, Timpanaro G, Cosentino S, Guarnaccia P. A Sustainable Organic Production Model for "Food Sovereignty" in the United Arab Emirates and Sicily-Italy. Sustainability 2018;10:620.

37. Rodríguez LC, González JAC. How to make prosperous and sustainable family farming in Cuba a reality. Elementa 2018;6:77.

38. Clarke N, Bizimana JC, Dile Y, et al. Evaluation of new farming technologies in Ethiopia using the Integrated Decision Support System (IDSS). Agric. Water Manag. 2017;180:267-279.

39. Tsolakis N, Srai JS. A System Dynamics approach to food security through smallholder farming in the UK. Chem. Eng. Trans. 2017;57:2023-2028

40. Sajjad H, Nasreen I. Assessing farm-level agricultural sustainability using site-specific indicators and sustainable livelihood security index: Evidence from Vaishali district, India. Community Dev. 2016;47:602-619.

41. Mundler P, Laughrea S. The contributions of short food supply chains to territorial development: A study of three Quebec territories. J. Rural Stud. 2016;45:218-229.

42. Reidsma P, Bakker MM, Kanellopoulos A, et al. Sustainable agricultural development in a rural area in the Netherlands? Assessing impacts of climate and socio-economic change at farm and landscape level. Agric. Syst. 2015;141:160-173.

43. Paracchini ML, Bulgheroni C, Borreani G, et al. A diagnostic system to assess sustainability at a farm level: The SOSTARE model. Agric. Syst. 2015;133:35-53.

44. Lucato WC, Costa EM, de Oliveira Neto GC. The environmental performance of SMEs in the Brazilian textile industry and the relationship with their financial performance. J. Environ. Manage. 2017;203:550-556.

45. Hák T, Janoušková S, Moldan B. Sustainable Development Goals: A need for relevant indicators. Ecol. Indic. 2016;60:565-573.

46. Prasara-A J, Gheewala SH. Sustainable utilization of rice husk ash from power plants: A review. J. Clean. Prod. 2017;167: 1020-1028.

47. Nishitani K, Jannah N, Kaneko S, Hardinsyah. Does corporate environmental performance enhance financial performance? An empirical study of indonesian firms. Environ. Dev. 2017;23:10-21.

48. Haffar M, Searcy C. The use of context-based environmental indicators in corporate reporting. J. Clean. Prod. 2018;192: 496-513.

49. Moghaddam SM, Nazari MR, Soufizadeh S. Integrating ecological impact indicators into economic restructuring decisions. Ecol. Indic. 2018;89:327-335.

50. Meneses-Jácome A, Diaz-Chavez R, Velásquez-Arredondo HI, Cárdenas-Chávez DL, Parra R, Ruiz-Colorado AA. Sustainable Energy from agro-industrial wastewaters in Latin-America. Renew. Sustain. Energy Rev. 2016;56:1249-1262.
51. Gonzalez-Garcia S, Manteiga R, Moreira MT, Feijoo G. Assessing the sustainability of Spanish cities considering environmental and socio-economic indicators. J. Clean. Prod. 2018;178: 599-610.

52. Global Reporting Initiative (GRI). G4 Sustainability Reporting Guidelines - Part 1: Reporting Principles and Standard Disclosures. Amsterdam, The Netherlands; 2013.

53. Nunes ACP, Reis LMM, Silva RG. Indicadores ambientais de sustentabilidade para uma instituição federal de ensino superior. Confins. Revue franco-brésilienne de géographie 2017;30:11812.

54. Rasmussen LV, Bierbaum R, Oldekop JA, Agrawal A. Bridging the practitioner-researcher divide: Indicators to track environmental, economic, and sociocultural sustainability of agricultural commodity production. Global Environ. Change 2017;42: 33-46.

55. Chaudhary A, Gustafson D, Mathys A. Multi-indicator sustainability assessment of global food systems. Nat. Commun. 2018;9:848.

56. Liu G, Li M, Zhou B, Chen Y, Liao S. General indicator for techno-economic assessment of renewable energy resources. Energy Convers. Manage. 2018;156:416-426.

57. Jackson T, Roberts P. A Review of Indicators of Sustainable Development: a report for Scottish Enterprise Tayside. Scottish Enterprise Tayside. 2000.

58. Balkema AJ, Preisig HA, Otterpohl R, Lambert FJD. Indicators for the sustainability assessment of wastewater treatment systems. Urban Water 2002;4:153-161.

59. Naqvi M, Yan J, Dahlquist E, Naqvi SR. Off-grid electricity generation using mixed biomass compost: A scenario-based study with sensitivity analysis. Appl. Energy 2017;201:363-370.

60. Butt B. Environmental indicators and governance. Curr. Opin. Environ. Sustainability 2018;32:84-89.

61. Dong Y, Hauschild MZ. Indicators for Environmental Sustainability. Procedia CIRP 2017;61:697-702.

62. Simas M, Pauliuk S, Wood R, Hertwich EG, Stadler K. Correlation between production and consumption-based environmental indicators. Ecol. Indic. 2017;76:317-323.

63. Bui T, Tran H, Azadi H, Lebailly P. Improving the Technical Efficiency of Sengcu Rice Producers through Better Financial Management and Sustainable Farming Practices in Mountainous Areas of Vietnam. Sustainability 2018;10:2279.

64. Tisdell C. Economic indicators to assess the sustainability of conservation farming projects: An evaluation. Agric. Ecosyst. Environ. 1996;57:117-131.

65. Cox C, Jin L, Ganjegunte G, Borrok D, Lougheed V, Ma L. Soil quality changes due to flood irrigation in agricultural fields along the Rio Grande in western Texas. Appl. Geochem. 2018;90:87-100.

66. Boncinelli F, Casini L. A comparison of the well-being of agricultural and non agricultural households using a multicriterial approach. Social Indic. Res. 2014;119:183-195.

67. Veveris A, Šapolaitė V, Raišienė AG, Bilan Y. How Rural Development Programmes Serve for Viability of Small farms? Case of Latvia and Lithuania. Agris On-line Pap. Econ. Inf. 2019;11:103-113.

68. Sjauw-Koen-Fa AR, Omta SWFO, Blok V. Constructing a 
Multinationals' Inclusive Sourcing Indicator for Impacting Farmer Business Models: Application in Cocoa Cases. Int. J. Food Syst. Dyn. 2018;9:207-225.

69. Omondi I, Rao EJO, Karimov AA, Baltenweck I. Processor Linkages and Farm Household Productivity: Evidence from Dairy Hubs in East Africa. Agribusiness 2017;33:586-599.

70. Gerschewski S, Xiao SS. Beyond financial indicators: An assessment of the measurement of performance for international new ventures. Int. Bus. Rev. 2015;24:615-629.

71. Sousa WD, Melo FKEd, Sousa EPd. Sustainability of family farming in the municipality of barro. CE Revista Gestão $\mathcal{E}$ Sustentabilidade Ambiental 2017;6:26.

72. Carvalho JR, Marques D, Carvalho EKMdA, Lira WS. Estudo dos indicadores de sustentabilidade da agricultura familiar: o caso da comunidade de Vieirópolis, PB. Revista Meio Ambiente e Sustentabilidade 2013;4:243-263.

73. Gonçalves BDF, Vital TW. Analysis of sustainability of the rural area in Triunfo, Brazil (PE). Revista em Agronegócio e Meio Ambiente 2019;12:195-218.

74. Hein AF, da Silva NLS. Sustainable rural development indicators in awarded rural properties in Marechal Cândido Rondon, Paraná, Brazil. Revista Verde de Agroecologia e Desenvolvimento Sustentável 2019;14:603-611.

75. Martinez EA, Casalinho HD, de Lima ACR, Schwengber JE. Oferta de serviços ambientais a partir de diferentes agroecossistemas de base familiar no sul do Rio Grande do Sul.
Agricultura Familiar: Pesquisa, Formação e Desenvolvimento 2017;11:71-86.

76. Santos JG, Cândido GA. Sustainability and family agriculture: A case study in a rural farmer association. Revista de Gestão Social e Ambiental 2013;7:70-86.

77. Schwab PI, Moraes JLA, Bassan DS. Socioeconomic sustainability indicators of rural development in the city of Rolante/ /RS. DRd-Desenvolvimento Regional em debate 2020;10:370-386.

78. Deggorone ZA, Costa JFRd. Indicators of sustainability in food production: an analysis on the production of vegetables in the municipality of Erechim. RS. Revista Gestão e Sustentabilidade Ambiental 2018;7:31.

79. Araujo AVd, Brandão Junior DdS, Colen F. Energetic analysis of landrace varieties and hybrids of corn produced in different technological levels of management. Engenharia Agrícola 2013;33:625-635.

80. Márquez Romero F, Julca Otiniano A, Canto Saenz M, Soplín Villacorta H, Vargas Winstanley S, Huerta Fernández P. Sustentabilidad ambiental en fincas cafetaleras después de un proceso de certificación orgánica en la convención (Cusco, Perú). Ecología Aplicada 2016;15:125-132.

81. Machado Neto AdS, Ponciano NJ, Souza PMd, Gravina GdA, Daher RF. Costs, viability and risks of organic tomato production in a protected environment. Revista Ciência Agronômica 2018;49:584-591. 